\title{
CCL8 wt Allele
}

National Cancer Institute

\section{Source}

National Cancer Institute. CCL8 wt Allele. NCI Thesaurus. Code C49751.

Human CCCL8 wild-type allele is located within $17 q 11.2$ and is approximately $2 \mathrm{~kb}$ in length. This allele, which encodes C-C motif chemokine 8 protein, plays a role in the chemotaxis of monocytes, lymphocytes, basophils and eosinophils. The recruitment of leukocytes may contribute to tumor-associated leukocyte infiltration and to the antiviral state against HIV infection. 